\title{
Zabytkowy zespół alej w Radziejowicach - kulturowe dziedzictwo Mazowsza Ocena stanu zachowania i wartości obiektu
}

\section{Beata Fortuna-Antoszkiewicz, Jan Łukaszkiewicz}

\begin{abstract}
STRESZCZENIE
Opracowane studium obiektu - zabytkowego zespołu alej w Radziejowicach, woj. mazowieckie - służyło określeniu jego wyjątkowych walorów kulturowych i przyrodniczych, jako cennej formy zadrzewienia przydrożnego, będącej pozostałością po dawnym, historycznym systemie lokalnych gościńców.

Celem badań było określenie aktualnych zasobów drzewostanu zespołu alej (w zakresie taksonomicznym, przestrzennym, ilościowym i jakościowym) na potrzeby bieżącej pielęgnacji i dalszego zachowania układu. Ocenie poddano też stopień zachowania oryginalnego, historycznego układu, ze wskazaniem na szacunkowy wiek tworzących go drzew. Ocena wieku i czasu powstania układu alejowego w Radziejowicach opierała się na badaniach historycznych (kwerenda materiałów archiwalnych) oraz badaniach bezpośrednich w obiekcie - poprzez ocenę wieku drzew, tworzących aleje. Wytypowano drzewa szczególnie cenne (egzemplarze okazowe - ze względu na stan, pokrój i walory krajobrazowe), a także egzemplarze reliktowe - pozostałość oryginalnych XIX-wiecznych nasadzeń.

Badaniami objęto zespół alej w ulicach: al. Lipowa, ul. Henryka Sienkiewicza, ul. Główna, ul. Jakuba Kubickiego. Podczas prac terenowych wykonano szczegółową inwentaryzację dendrologiczną wraz z oceną stanu zdrowotnego drzew (wrzesień - październik 2015 r.).

Radziejowicki zespół alejowy, w postaci rozbudowanego układu, powstał w latach 20. i 30. XIX w. Obecnie aleje charakteryzują się znacznym zróżnicowaniem tworzącego je drzewostanu oraz odrębnym charakterem ulic i dróg, wzdłuż których jest zlokalizowany. Ponad połowę drzew stanowią lipy drobnolistne (Tilia cordata Mill.); towarzysząco występuje klon pospolity (Acer platanoides L.), a w domieszce m.in. kasztanowiec pospolity (Aesculus hippocastanum L.), grab pospolity (Carpinus betulus L.), jesion wyniosły (Fraxinus excelsior L.). W zespole alej występuje 31 drzew o obwodach pni (mierzonych na wysokości 1,3 m) od $300 \mathrm{~cm}$ wzwyż czyli w wieku powyżej 180 lat (cenne zasoby materialne). Stopień zachowania układu, jako formy przestrzennej, funkcjonującej w określonych warunkach siedliskowych i przestrzennych, szacuje się na ok. $36 \%$.
\end{abstract}

Słowa kluczowe: zabytkowe aleje, krajobraz Mazowsza, walory kulturowe i przyrodnicze alej, elementy dziedzictwa kulturowego

\section{Wstęp}

Zabytkowy zespół alej w Radziejowicach, woj. mazowieckie - jego powstanie oraz obecny przebieg wiążą się ściśle z radziejowickim założeniem pałacowo-parkowym - dawną siedzibą rodów Radziejowskich i Krasińskich. Opracowane studium obiektu [FortunaAntoszkiewicz i in. 2015] służyło określeniu jego wyjątkowych walorów kulturowych i przyrodniczych, jako cennej formy zadrzewienia przydrożnego, będącej pozostałością po dawnym, historycznym systemie lokalnych dróg i gościńców.

Celem badań było określenie aktualnych zasobów drzewostanu zespołu alej (w zakresie taksonomicznym, przestrzennym, ilościowym i jakościowym) na potrzeby bieżącej pielęgnacji i dalszego zachowania układu. Ocenie poddano też stopień zachowania oryginalnego, historycznego układu, ze wskazaniem na szacunkowy wiek tworzących go 
Fot. 1. Al. Lipowa (sektor A) - fragmenty ok. 200-letniego starodrzewu (w głębi lipy nr inw. 16-18)

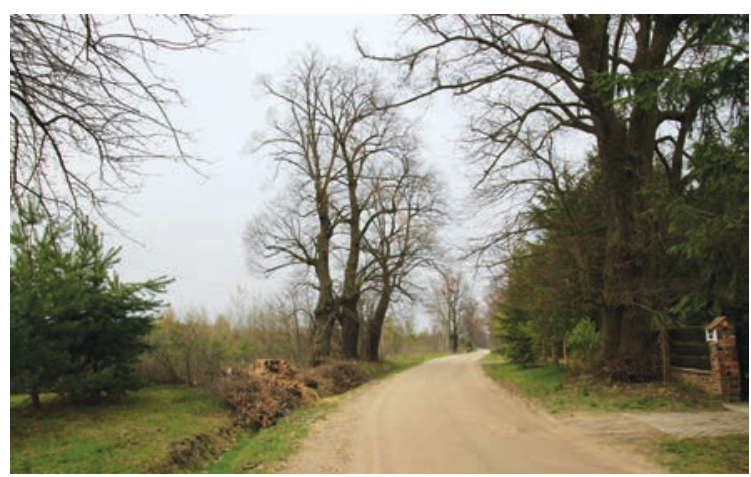

Fot. P. Wiśniewski, kwiecień 2016 drzew. Ocena wieku i czasu powstania układu alejowego w Radziejowicach opierała się na badaniach historycznych (kwerenda materiałów archiwalnych) oraz badaniach bezpośrednich w obiekcie - poprzez ocenę wieku drzew, tworzących aleje. Wytypowano drzewa szczególnie cenne (egzemplarze okazowe - ze względu na stan, pokrój i walory krajobrazowe), a także egzemplarze reliktowe - pozostałość oryginalnych XIX-wiecznych nasadzeń (fot. 1., fot. 2, fot. 3).

Badaniami objęto zespół alej w ulicach: al. Lipowa, ul. Henryka Sienkiewicza, ul. Główna, ul. Jakuba Kubickiego. Podczas prac terenowych wykonano szczegółową inwentaryzację dendrologiczną wraz z oceną stanu zdrowotnego drzew (wrzesień - październik 2015 r.).
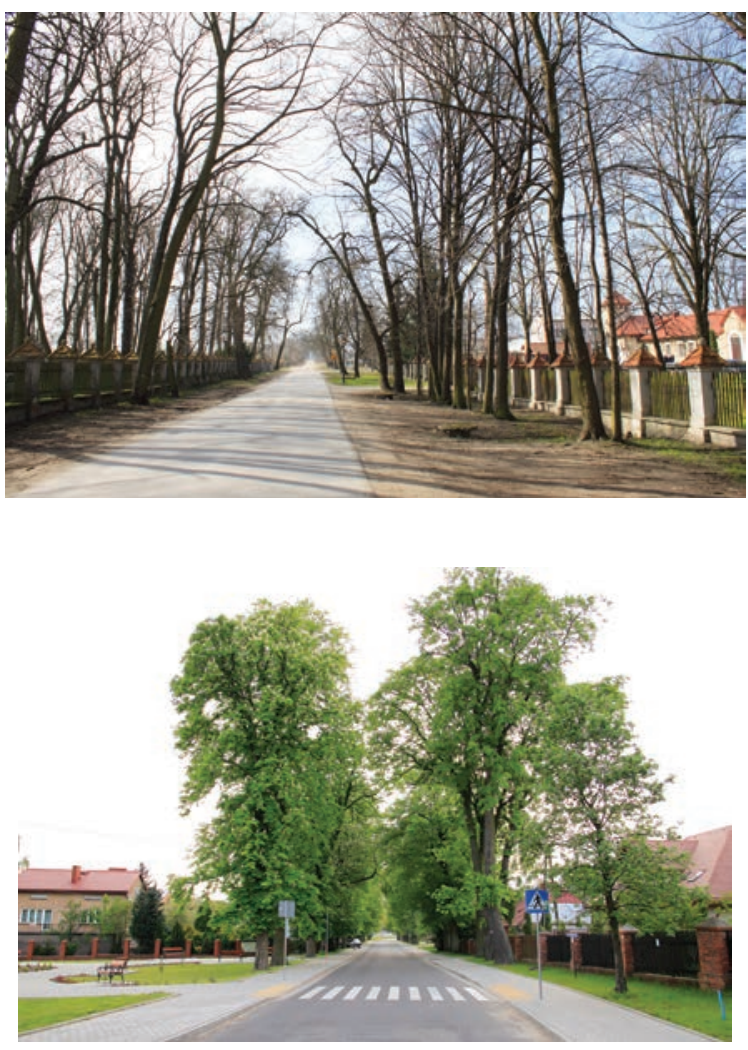

Fot. 2. UI. Henryka Sienkiewicza (sektor B)

Widok ogólny drzewostanu alei w kierunku południowym, stan bezlistny wczesną wiosną. Sylwety drzew są bardzo smukłe ze względu na konkurencję $z$ drzewostanem parku oraz $z$ powodu podkrzesywania koron

Fot. P. Wiśniewski, marzec 2015

Fot. 3. UI. Jakuba Kubickiego (sektor D)

Widok ogólny starodrzewu alei w kierunku południowym - od kościoła w stronę ronda

Fot. P. Wiśniewski, maj 2015 


\section{Aleje w krajobrazie}

Rygorystyczne, regularne obsadzenia dróg prowadzących do rezydencji, zawsze świadczyło o prestiżu miejsca i znaczeniu właściciela dóbr [Fortuna-Antoszkiewicz 2002]. Na ziemiach polskich proste gościńce, łączące dwory i folwarki, obsadzano drzewami już od XVI w. Do XVIII w. dotyczyło to przede wszystkim dróg prywatnych. Drogi publiczne zaczęto obsadzać drzewami od połowy XVIII w., a stałą zasadą stało się to dopiero w XIX w. [Łuczyńska-Bruzda 1995].

Zasadnicze zmiany w sposobie wykorzystania układów alejowych przyniosły czasy baroku i późniejszego Oświecenia. Okres XVII i XVIII wieku zaowocował zmianami w krajobrazie całej Europy, czytelnymi w urbanistycznych układach przestrzennych aż do czasów współczesnych. Jednym z instrumentów kształtowania pejzażu w tak wielkiej skali były aleje, które przyjmowały charakter monumentalny i reprezentacyjny. W tym okresie aleje podlegały ściśle określonym regułom dotyczącym struktury nasadzeń i doboru gatunkowego stosowanych drzew [Siewniak 1990; Majdecki 1993; Fortuna-Antoszkiewicz 2004].

W krajobrazie otwartym rozpoczęło się masowe zakładanie alej. Prekursorami byli królowie francuscy, którzy ustawiając drzewa w regularnych szeregach podkreślali potęgę władzy absolutnej. Następnie moda rozprzestrzeniła się w całej Europie, docierając szybko do Polski. Pierwsze wielkie aleje zakładał król Jan III Sobieski, a wkrótce znalazł szereg naśladowców [Fortuna-Antoszkiewicz 2002].

Na przestrzeni wieków do obsadzania alej stosowano liczne gatunki drzew, w zależności od mody i kraju. W Europie w różnych okresach historycznych, jako drzewa alejowe szczególnie ceniono lipy. Przykładowo lipa holenderska (Tilia ×europea L.) i lipa szerokolistna (Tilia platyphyllos Scop.) były często sadzone na terenie Anglii, Francji i Niemiec [Pigott

Fot. 4. Przykład XIX-wiecznego drzewa alejowego - stara lipa drobnolistna o modelowym pokroju i w pełni witalna (nr inw. 9, podsektor A1, al. Lipowa)

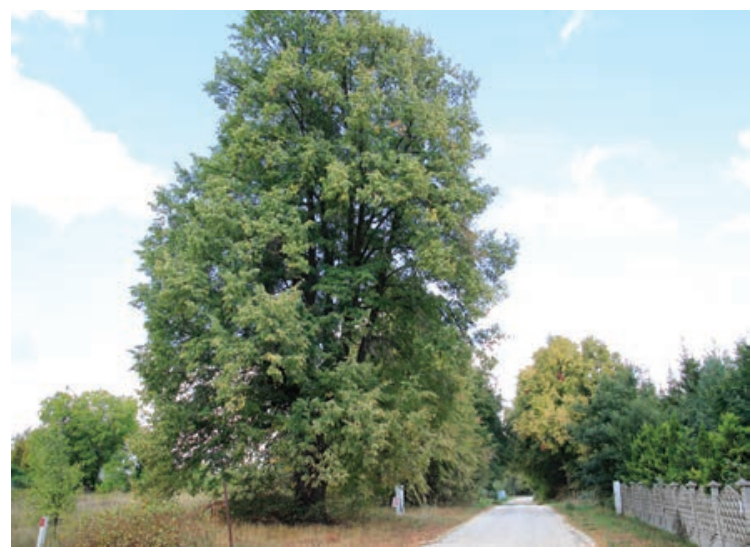

Fot. P. Wiśniewski, wrzesień 2015
1989; Siewniak i in. 1991]. W Polsce jako drzewo alejowe często stosowano lipę drobnolistną (Tilia cordata Mill.), gatunek rodzimy i pospolity (fot. 4). Poza lipami w alejach sadzono także klony pospolite (Acer platanoides L.), jarzęby (Sorbus sp.), topole (później mieszańce topól) (Populus sp.). Od końca XIX w. nastała moda na sadzenie drzew owocowych (Juglans regia L., Malus sp., Morus sp., Prunus sp., Pyrus sp.) [Fortuna-Antoszkiewicz, Łukaszkiewicz 2012a], jesionu pensylwańskiego (Fraxinus pensylvanica Marshall) i robinii białej (Robinia pseudoacacia L.) 
[Łuczyńska-Bruzda 1995]. Cenionym drzewem alejowym był kasztanowiec biały (Aesculus hippocastanum L.), a także buk pospolity (Fagus sylvatica L.) i wiąz szypułkowy (Ulmus laevis Pall.) oraz rzadziej stosowany - jesion wyniosły (Fraxinus excelsior L.). Na zachodzie Europy najchętniej sadzonym drzewem był i jest platan klonolistny (Platanus xhispanica Mill. ex Münchh. 'Acerifolia') [Majdecki 1993].

W krajobrazie Mazowsza stare aleje pełnią dziś szczególnie ważne funkcje przestrzenne. Razem z innymi formami zadrzewień wzbogacają fizjonomię i łagodzą monotonię terenów nizinnych. Mają one również istotne wartości historyczne i kulturowe. Aleje są bardzo często jedynymi „(...) ostańcami ojczystej przyrody, reliktami wiejskiego krajobrazu.... O ich historycznej roli należy bodaj wspomnieć. One przecież tączac dwory, wioski, miasta, i miasteczka wytyczały główne szlaki, którymi przebiegały wówczas wieści radosne lub trwożne. Tędy też wielokrotnie galopowaty polskie dzieje" [Szwarc-Bronikowski 2000].

\section{Charakterystyka obiektu}

\section{Powstanie}

W drugiej połowie XVIII w. (1782 r.) Radziejowice, dawna siedziba Radziejowskich, znalazły się w rękach rodu Krasińskich [Barbasiewicz 2016]. W XVIII w. z pewnością istniały tu regularne zadrzewienia towarzyszące drodze w kierunku Warszawy. Dokumentuje to m.in. obraz Jakuba Sokołowskiego z 1820 r. - w tym czasie drzewa przy drodze były już stare i zamierające, rosły głównie po jednej stronie drogi, wzdłuż drugiej pozostawały tylko pojedyncze egzemplarze - resztka analogicznego rzędu (ryc. 1).

\section{Ryc. 1. Panorama Radziejowic od strony północno-wschodniej, Jakub Sokołowski, ok. 1820 r.}

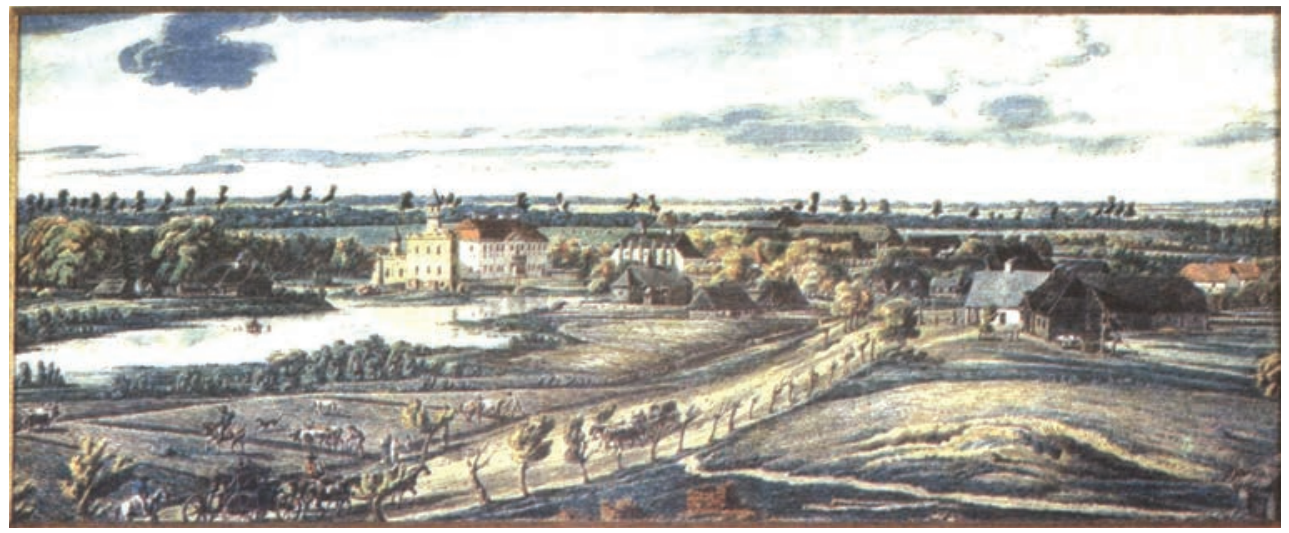

Na początku XIX w., za czasów Józefa Wawrzyńca Krasińskiego, odrestaurowano Zameczek i przebudowano pałac (proj. Jakub Kubicki). Klasycystyczną budowlę pałacu w 1817 r. otoczył nowy park - dawny ogród regularny przekształcono w park krajobrazowy (proj. pułkownik Aleksander d'Alphonce de Saint Omer - przyjaciel domu, kartograf i miłośnik ogrodnictwa). W części folwarcznej po 1820 r. wybudowano dworek 
modrzewiowy - mieszkanie administratora dóbr. W latach 1820-1822 Krasiński ufundował w Radziejowicach nowy, klasycystyczny kościół (proj. Jakub Kubicki) [Barbasiewicz 2016]. Kościół ulokowano na przeciwległym skraju osady, przy drodze prowadzącej w kierunku Warszawy. Zgodnie z panującymi wówczas trendami na obszarze majątku zastosowano charakterystyczne dla klasycyzmu wielkoskalowe rozwiązanie przestrzenne - główne dominanty architektoniczne (pałac i kościół) oraz punkty wjazdowe i wyjazdowe z miejscowości - powiązano systemem reprezentacyjnych alej. Jeden z fragmentów (obecna ul. H. Sienkiewicza) posłużył do oddzielenia głównej rezydencji (pałacu) od zabudowań gospodarczych i dworku administratora. Do drzew alejowych, chętnie wtedy stosowanych, należały lipy i kasztanowce, czego pozostałość lub formalna kontynuacja istnieje do dzisiaj.

\section{Granice terenu objętego badaniami}

Zasięg granic terenu objętego badaniami determinowany był przebiegiem gminnych ulic (historycznych dróg), które można podzielić na cztery odrębne fragmenty (ryc. 2):

- fragment 1. (dł. 1,4 km) - al. Lipowa na odcinku od styku z trasą szybkiego ruchu S8 a skrzyżowaniem z ul. Przemysłową (sektor A);

- fragment 2. (dł. 0,6 km) - ul. Henryka Sienkiewicza na odcinku pomiędzy skrzyżowaniem z ul. Przemysłową a skrzyżowaniem z ul. Główną (na wysokości założenia pałacowoparkowego w Radziejowicach) (sektor B);

- fragment 3. (dł. 0,35 km) - ul. Główna na odcinku pomiędzy skrzyżowaniem z ul. H. Sienkiewicza a rondem na skrzyżowaniu z ul. J. Kubickiego (sektor C);

- fragment 4. (dł. 0,37 km) - ul. Jakuba Kubickiego od ronda do skrzyżowania z ul. Ogarów Polskich (sektor D).

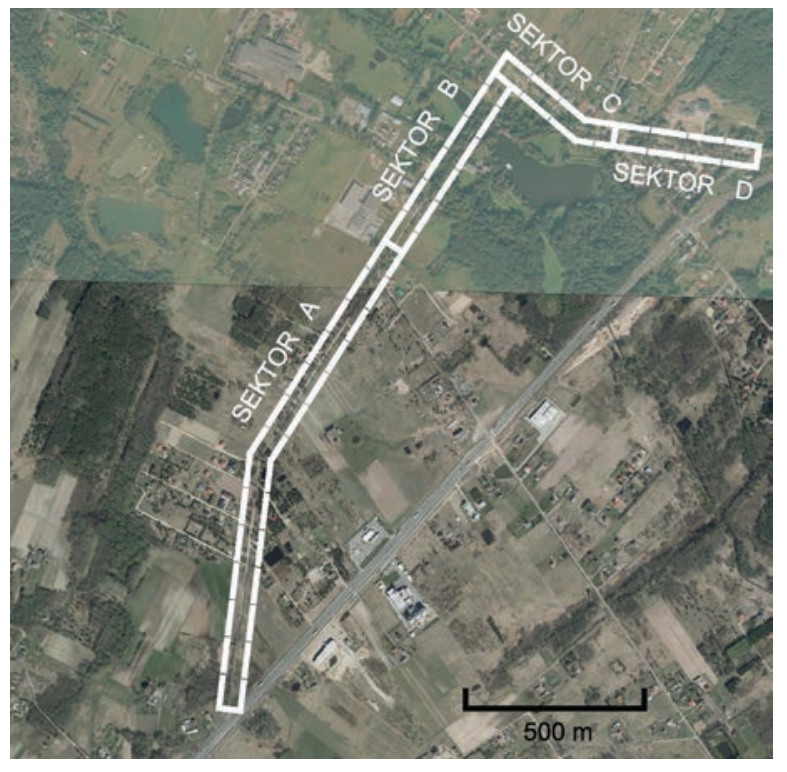

Ryc. 2. Lokalizacja zespołu alej w Radziejowicach

Opracowanie P. Wiśniewski na podstawie: Ortofotomapa w skali 1:5000 [Wyd. przez Urząd Marszałkowski Województwa Mazowieckiego w Warszawie, Departament Geodezji i Kartografii] 


\section{Współczesna forma użytkowania i pełnione funkcje}

Analizowane aleje stanowią lokalne ciagi komunikacji kołowej i pieszej o nawierzchni utwardzonej żwirowo-gruntowej (fragm. 1.) oraz nawierzchni bitumicznej (fragm. 2-4) - te ostatnie obsługują zwiększony, a okresowo intensywny ruch komunikacyjny. Obecnie aleje spełniają różnorodne funkcje:

- historyczną - jako ważna pozostałość dawnej sieci zadrzewień przydrożnych rozlokowanych na terenie południowo-zachodniego Mazowsza;

- kulturową - jedna z podstawowych tradycyjnych form zadrzewień w krajobrazie rolniczym; aleje były zakładane nie tylko ze względu na potrzeby komunikacyjne, ale pełniły także funkcje osi kompozycyjnych i widokowych, często łączących obszary rezydencjonalnych parków z innymi obiektami o charakterze dominant w okolicznym krajobrazie (np. kościoły, kaplice, folwarki i in.); poprzez rytm, światłocień, jednolitość masywu drzew można przypisać alejom pewne cechy form architektury [Siewniak i in. 1991; Majdecki 1993];

- przyrodniczą / biocenotyczną - alejowe formy zadrzewień przydrożnych oddziałują pozytywnie na warunki środowiska fauny (element systemu korytarzy ekologicznych pośród pól i terenów zabudowanych; miejsce bytowania ptaków, owadów itp.; kształtowanie środowiska owadów zapylających);

- techniczną - aleja, jako jedna z klasycznych form zadrzewień śródpolnych i przydrożnych spełnia określone funkcje ochronne [Hejmanowski i in. 1964; Łuczyńska-Bruzda 1995]: przeciwerozyjne, wiatrochronne, osłonowe (np. osłony przeciwśnieżnej dla dróg i okolicznych pól [Gradowski, Budzyński 1963]), zwiększanie wodnej retencji środowiska, ochronę roślin uprawnych przed zanieczyszczeniami komunikacyjnymi, wzmaganie oporu środowiska przeciw szkodnikom roślin uprawnych;

- rekreacyjno-turystyczną-obecność nasadzeń alejowych, zwłaszcza o cennych zabytkowych drzewostanach, wpływa zdecydowanie na zwiększenie turystycznowypoczynkowej atrakcyjności terenu.

\section{Status prawny}

Historyczny zespół alej w Radziejowicach objęty jest ochroną konserwatorską w rejestrze zabytków figuruje pod numerami:

- aleja jesionowa - przy drodze od zachodniej strony pałacu / 400 m / nr rejestru 545 z dn. 05.05.1980 r.

- aleja lipowa wzdłuż drogi przed pałacem / 300 m / nr rejestru 545 z dn. 05.05.1980 r.

- aleja lipowo-klonowo-kasztanowcowa - wzdłuż drogi do kościoła / 300 m / nr rejestru $545 \mathrm{z}$ dn. 05.05.1980 r.

- aleja lipowa - Radziejowice-Parcel / 700 m / nr rejestru 545 z dn. 05.05.1980 r.

- aleja lipowa - przy starym trakcie warszawskim (aleja 1-stronna) / $300 \mathrm{~m} / \mathrm{nr}$ rejestru 545 z dn. 05.05.1980 r. [Studium uwarunkowań i kierunków zagospodarowania przestrzennego gminy Radziejowice 2006]. 


\section{Wyniki - charakterystyka drzewostanu alej}

\section{Zbiór danych - prace terenowe}

W okresie wrzesień-październik 2015 r. przeprowadzono szczegółową inwentaryzację drzewostanu alejowego (ryc. 3). Do pomiarów drzew zastosowano cirkometr/taśmę miernicza, wysokościomierz oraz dalmierz laserowy z funkcją pomiaru odległości i wysokości. Zakres prac terenowych obejmował:

- identyfikację poszczególnych egzemplarzy roślin drzewiastych, ze wskazaniem ich lokalizacji na mapie inwentaryzacyjnej wraz z przypisaną numeracją porządkową;

- określenie nazw taksonomicznych drzew na podstawie cech morfologicznych, zgodnie z obowiązującą nomenklaturą botaniczną [Seneta, Dolatowski 2012];

- pomiary parametrów drzew:

- obwód pnia na standardowej wysokości pierśnicowej 1,3 m n.p.t. (cm); w przypadku, gdy pomiar obwodu na typowej wysokości nie był możliwy ze względu na anomalie w kształcie pnia, pomiar przeprowadzano na innej wysokości zgodnie z zasadami przyjętymi przez ISA [ISA - International Society of Arboriculture. Tree Ordinance Guidelines];

- nachylenie pnia (stopnie kątowe);

- wysokość całkowita - pomiar z dokładnością od 0,25-0,5 m (m);

- średni zasięg rzutu korony (m);

- rozmiary powierzchniowych i wgłębnych uszkodzeń pni $(\mathrm{m} / \mathrm{cm})$;

- odległości pomiędzy drzewami (rozstawa) (m);

- określenie kondycji zdrowotnej - każdy zinwentaryzowany egzemplarz podlegał ogólnej ocenie stanu zdrowotnego, w tym występujących wad i uszkodzeń oraz objawów chorobowych (oddziaływanie patogenów); charakteryzowano cechy pokrojowe drzew oraz warunki ich otoczenia;

- szacowanie wieku drzew reprezentatywnych na podstawie liczby rocznych przyrostów

\section{Ryc. 3. Fragment mapy szczegółowej inwentaryzacji drzewostanu alej w Radziejowicach - ul. Jakuba Kubickiego (sektor D)}

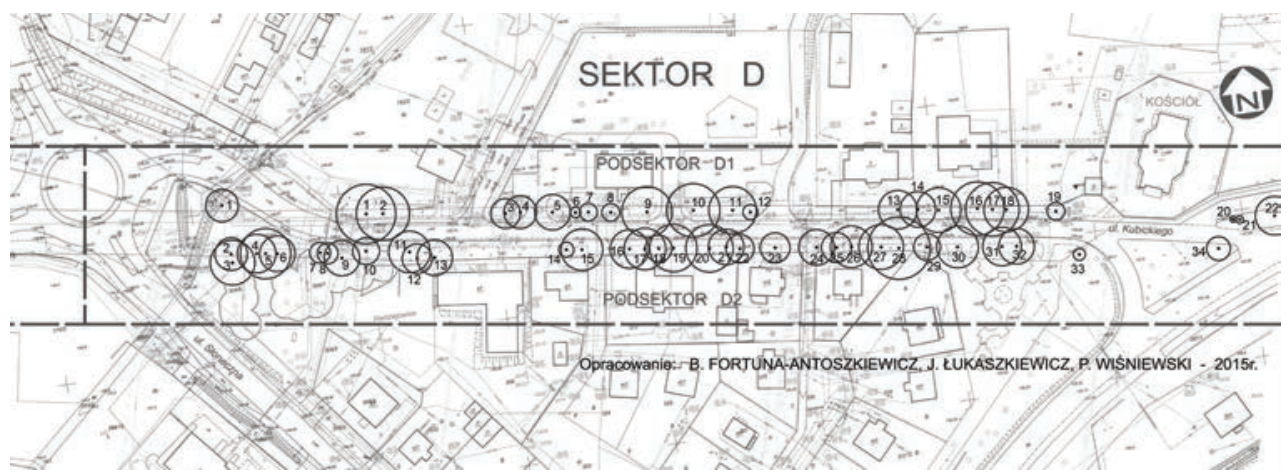

Żródło: B. Fortuna-Antoszkiewicz i in. 2015 
drewna na pniakach drzew ściętych lub obalonych (dendrochronologia [Zielski, Krąpiec 2004]) w celu oszacowania przeciętnego wieku dla wyodrębnionych fragmentów drzewostanu alei; wskazanie egzemplarzy cennych przyrodniczo, historycznie (egzemplarze najstarsze), krajobrazowo (egzemplarze o wybitnych cechach pokrojowych, witalne);

- pomiary współrzędnych geograficznych dla charakterystycznych miejsce przebiegu alei (na podstawie GPS);

- wykonanie dokumentacji fotograficznej.

\section{Metody opracowania wyników}

Dane zgromadzone podczas prac terenowych zestawiono w tabelach inwentaryzacyjnych. Tabele zawierają numerację porządkową zgodną z numeracją na mapie inwentaryzacji w skali 1:500, oprac. na mapie sytuacyjno-wysokościowej w skali 1:500 [Mapa sytuacyjnowysokościowa w skali 1:500, 2015 r., obręb: Radziejowice, Radziejowice-Parcel, Kuranów, Wyd. przez Starostwo Powiatowe w Żyrardowie]. Każde zinwentaryzowane drzewo ma przypisaną botaniczną nazwę łacińską i polską taksonu oraz określone parametry: pierśnicowy obwód pnia (lub pni), wysokość, średni zasięg korony. Ponadto tabela zawiera informacje dotyczące m.in. cech pokrojowych, wad i uszkodzeń oraz stanu zdrowotnego drzew. Mapa inwentaryzacji drzewostanu (część graficzna) przedstawia jej poszczególne fragmenty objęte inwentaryzacją szczegółową.

Analiza danych zgromadzonych podczas prac terenowych obejmowała charakterystykę zasobów drzewostanu oraz walorów krajobrazowych zespołu alej w Radziejowicach. Ocenie poddano też stopień zachowania oryginalnego, historycznego układu, ze wskazaniem na szacunkowy wiek tworzących go drzew.

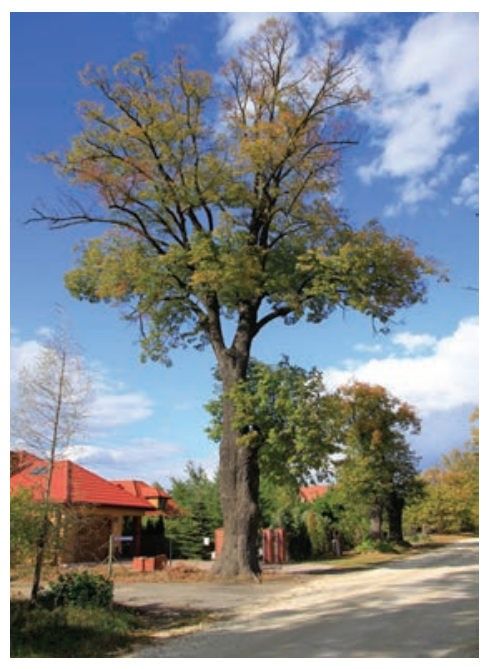

\section{Struktura gatunkowa i ilościowa drzewostanu zespołu alej / egzemplarze cenne}

Obecnie zespół alej w Radziejowicach charakteryzuje się mieszanym składem gatunkowym drzewostanu. Aleje łącznie tworzy 213 drzew należących do 19 gatunków, z czego ponad połowę (108 szt.) stanowią lipy drobnolistne (Tilia cordata Mill.). Wskazuje to wyraźnie, że radziejowickie założenie alejowe oryginalnie w znacznej mierze obsadzone było lipami (fot. 5).

Fot. 5. Al. Lipowa - lipa drobnolistna (obw. $361 \mathrm{~cm}$ ), nr inw. 25, podsektor A1

Fot. P. Wiśniewski, wrzesień 2015 


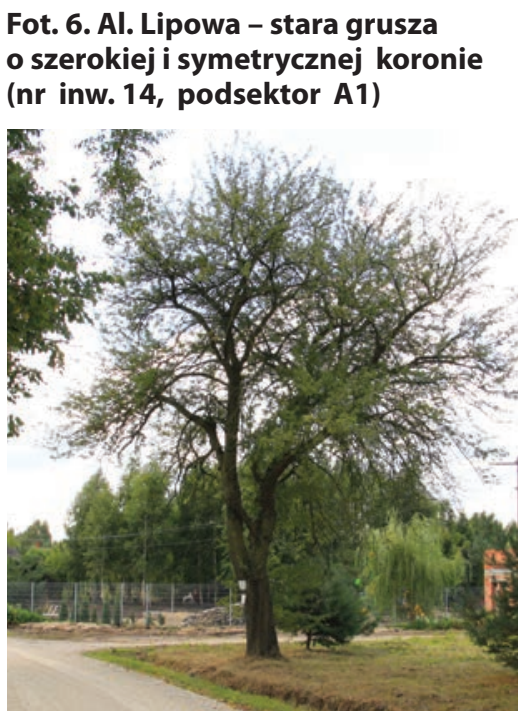

Fot. P. Wiśniewski, wrzesień 2015
W skali badanego drzewostanu skład gatunkowy pod względem ilościowym przedstawia się następująco:

- dominuje lipa drobnolistna (Tilia cordata Mill.) 108 szt. (ok. 50\% wszystkich drzew w alejach);

- towarzysząco występuje klon pospolity (Acer platanoides L.) - 33 szt. (15\%);

- jako domieszka pojawiają się m.in.: kasztanowiec pospolity (Aesculus hippocastanum L.) - 13 szt. (6\%), grab pospolity (Carpinus betulus L.) - 10 szt. (ok. $5 \%$ ) oraz jesion wyniosły (Fraxinus excelsior L.) -7 szt. (ok. 3\%);

- pozostałe gatunki występują pojedynczo tworząc grupę 31 szt. (ok. 15\% w skali całego drzewostanu) - np. dąb szypułkowy, grusza, lipa holenderska, lipa szerokolistna, olsza czarna, robinia biała, topola późna, wierzba biała (fot. 6).

Najcenniejszy fragment zadrzewień stanowi odcinek alei Lipowej (sektor A) - głównie na tym odcinku zachowały się drzewa pochodzące $\mathrm{z}$ najstarszych, oryginalnych nasadzeń. $\mathrm{Z}$ tego względu $\mathrm{w}$ niniejszym artykule najwięcej uwagi poświęcono temu właśnie fragmentowi.

W sektorze A wyodrębniono 2 podsektory: podsektor A1 - obejmujący zachodnią stronę drogi oraz podsektor A2 ze wschodnią stroną drogi.

W podsektorze A1 rosną 43 drzewa przynależące do 5 gatunków. Dominuje lipa drobnolistna (Tilia cordata Mill.) - 35 szt. (ok. 90\% wszystkich drzew w podsektorze). Wśród gatunków domieszkowych występują grusze (mieszańce). Interesującą kategorią są tu drzewa starsze, które ze względu na swoje rozmiary i wiek należały najprawdopodobniej do oryginalnego, historycznego drzewostanu alei - w tej grupie wymienić można aż 14 lip, których pierśnicowe obwody pni mieszczą się w przedziale 301$400 \mathrm{~cm}$. Największa z lip po tej stronie drogi osiągnęła obwód pnia 447 cm (!) (fot. 7).

Fot. 7. Al. Lipowa - największa w tym podsektorze (obw. $447 \mathrm{~cm}$ ), bardzo żywotna stara lipa o foremnej, symetrycznej koronie, ale i z poważnym uszkodzeniem - miejscem po wyłamanym przewodniku (nr inw. 41, podsektor A1)

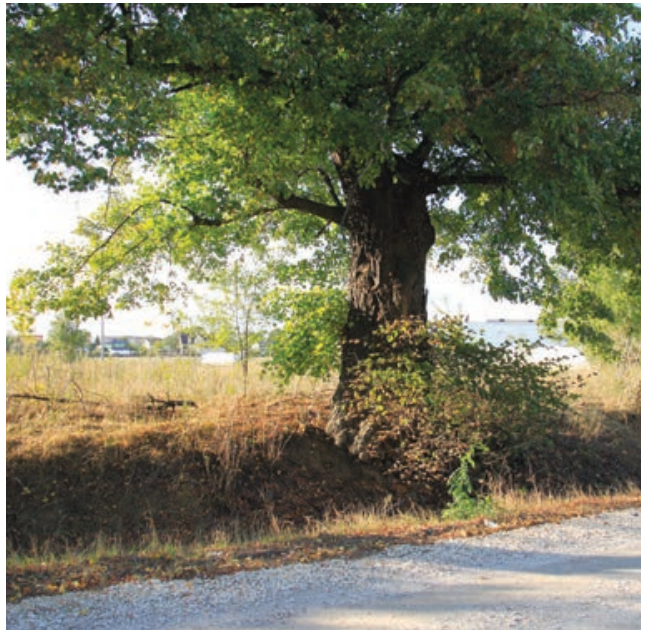

Fot. P. Wiśniewski, wrzesień 2015 
Fot. 8. Al. Lipowa - „wieniec" starych odrośli w miejscu, gdzie znajdowało się drzewo mateczne (nr inw. 12, podsektor A1)(nr inw. 41, podsektor A1)

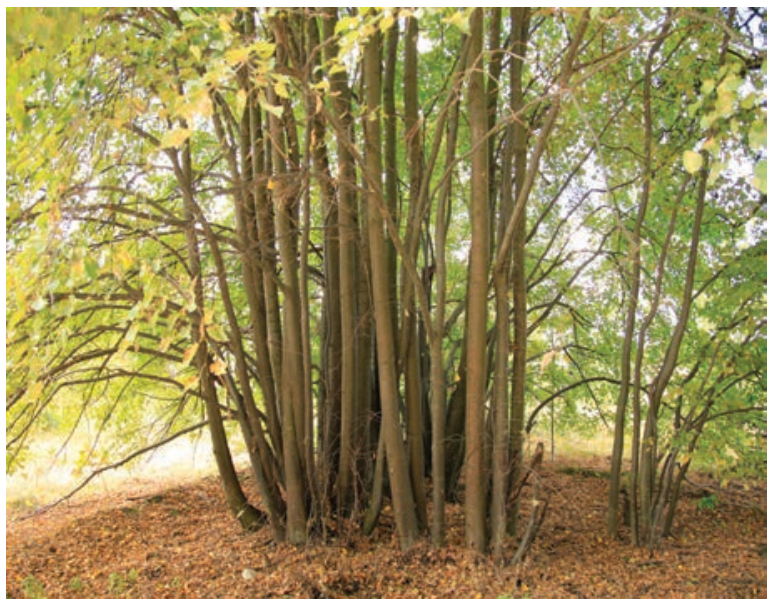

Fot. P. Wiśniewski, wrzesień 2015
Wyraźnie można wskazać drzewa, które charakteryzują się wybitnymi walorami krajobrazowymi ze względu na osiągane rozmiary, pokrój i witalność - do tej kategorii zalicza się 13 lip oraz 2 grusze. Występują tu także pozostałości (relikty) po oryginalnych drzewach alejowych (lipy) w postaci starych karp (resztki pniaków) - 3 szt. oraz „wieńcowatych" grup/skupisk drzew wyrosłych z odrośli z nasady pni drzew matecznych - 11 szt. (fot. 8). Mają one niezbywalną wartość historyczną - wskazują lokalizację nasadzeń oryginalnych oraz stanowią cenną pulę genową.

W podsektorze A2 rośnie 40 drzew przynależących do 6 gatunków. Dominuje lipa drobnolistna (Tilia cordata Mill.) - 28 szt. (ok. 70\% wszystkich drzew w podsektorze). Gatunki domieszkowe to: olsza czarna (4 szt.), grab pospolity (3 szt.). Pojedynczo występują: robinia biała (2 szt.), grusza polna (2 szt.). W kategorii drzew starszych (egzemplarze pochodzące z oryginalnego, historycznego drzewostanu) wymienić można 6 lip, których pierśnicowe

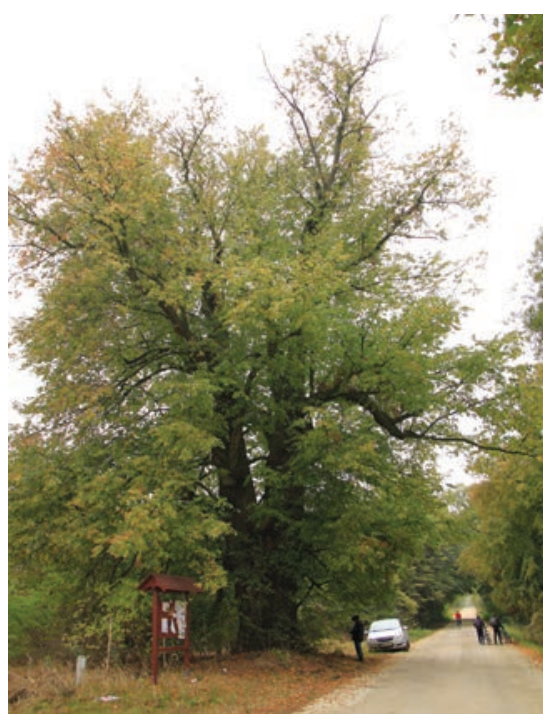

Fot. P. Wiśniewski, wrzesień 2015 obwody pni mieszczą się w przedziale $301-400 \mathrm{~cm}$ oraz 2 lipy o obwodach w przedziale $401-500 \mathrm{~cm}$. Największa z lip w podsektorze A2 (a zarazem największa lipa w całej alei) osiągnęła obwód pnia $533 \mathrm{~cm}$ (!) (fot. 9).

Do kategorii drzew o wybitnych walorach krajobrazowych (ze względu na osiągane rozmiary, pokrój i witalność) zaliczyć można 11 lip. Występują tu także pozostałości (relikty) po oryginalnych drzewach alejowych (lipy) w postaci starych karp (resztki pniaków) - 1 szt. oraz „wieńcowatych” grup/skupisk drzew wyrosłych z odrośli z nasady pni lip matecznych -4 szt.

Fot. 9. Al. Lipowa - największa lipa drobnolistna w zespole alej - drzewo o charakterze pomnika przyrody (obw. $533 \mathrm{~cm} / \mathrm{nr}$ inw. 36, podsektor A2) 
Tabela 1. Struktura gatunkowa drzewostanu - sektor A (podsektor A1 i A2), aleja Lipowa, Radziejowice

\begin{tabular}{|l|l|c|}
\hline \multicolumn{2}{|c|}{ Ilościowy udział gatunków drzew - sektor A } \\
\hline Nazwa botaniczna & Nazwa polska & (szt.) \\
\hline Tilia cordata & lipa drobnolistna & 53 \\
\hline Pyrus sp. & grusza (mieszańce) & 4 \\
\hline Alnus glutinosa & olsza czarna & 3 \\
\hline Carpinus betulus & grab pospolity & 2 \\
\hline Tilia xeuropaea & lipa holenderska & 2 \\
\hline Robinia pseudoacacia & robinia biała & 2 \\
\hline Salix alba & wierzba biała & 1 \\
\hline Quercus robur & dąb szypułkowy & 82 \\
\hline & razem & 2 \\
\hline
\end{tabular}

W kategorii drzew starszych - historycznych w pozostałych sektorach wyodrębniają się pojedyncze egzemplarze drzew:

Fot. 10. Największe drzewo przy ul. Jakuba Kubickiego (podsektor D2) - lipa drobnolistna, obw. $349 \mathrm{~cm}$ (nr inw. 28)

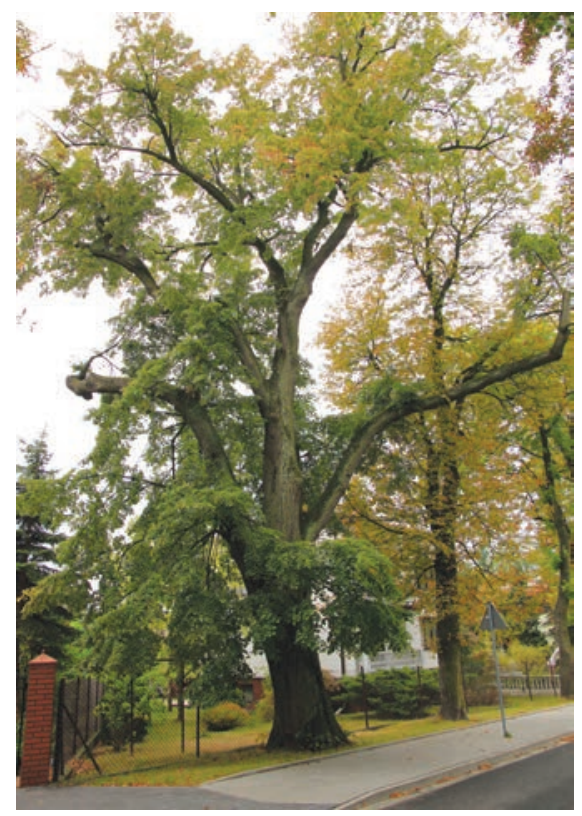

Fot. P. Wiśniewski, wrzesień 2015
- podsektor B1-6 lip o pierśnicowych obwodach pni mieszczących się w przedziale $201-300 \mathrm{~cm}$; 3 lipy o obwodach w przedziale $301-400 \mathrm{~cm}$;

- podsektor B2 - 5 lip oraz 1 jesion o pierśnicowych obwodach pni mieszczących się w przedziale 201-300 cm; 1 lipa o obwodzie w przedziale $301-400 \mathrm{~cm}$;

- sektor C - 2 lipy, 1 klon pospolity oraz 1 robinia o pierśnicowych obwodach pni mieszczących się w przedziale $201-300 \mathrm{~cm}$;

- podsektor D1 - 5 klonów, 2 lipy oraz 2 kasztanowce o pierśnicowych obwodach pni mieszczących się $\mathrm{w}$ przedziale $201-300 \mathrm{~cm}$; 1 klon i 1 lipa o obwodzie w przedziale 301-400 cm; 1 lipa o obwodzie 409 cm(!);

- podsektor D2 - 4 lipy, 3 klony oraz 1 kasztanowiec o pierśnicowych obwodach pni mieszczących się w przedziale 201-300 $\mathrm{cm}$; 2 lipy drobnolistne mają obwody pni w przedziale $301-400 \mathrm{~cm}$ (fot. 10). 
74 | ZABYTKOWY ZESPÓŁ ALEJ W RADZIEJOWICACH - KULTUROWE DZIEDZICTWO...

Beata Fortuna-Antoszkiewicz, Jan Łukaszkiewicz

\section{Ocena stanu drzew}

Pewna liczba drzew rosnących $\mathrm{w}$ alejach $\mathrm{w}$ Radziejowicach ma różnego rodzaju uszkodzenia oraz symptomy świadczące o pogorszonym stanie zdrowotnym (ryc. 4):

\section{Ryc. 4. Drzewa silnie uszkodzone lub o pogorszonej żywotności - aleje w Radziejowicach z podziałem na sektory}

Liczba drzew silnie uszkodzonych lub o pogorszonej żywotności

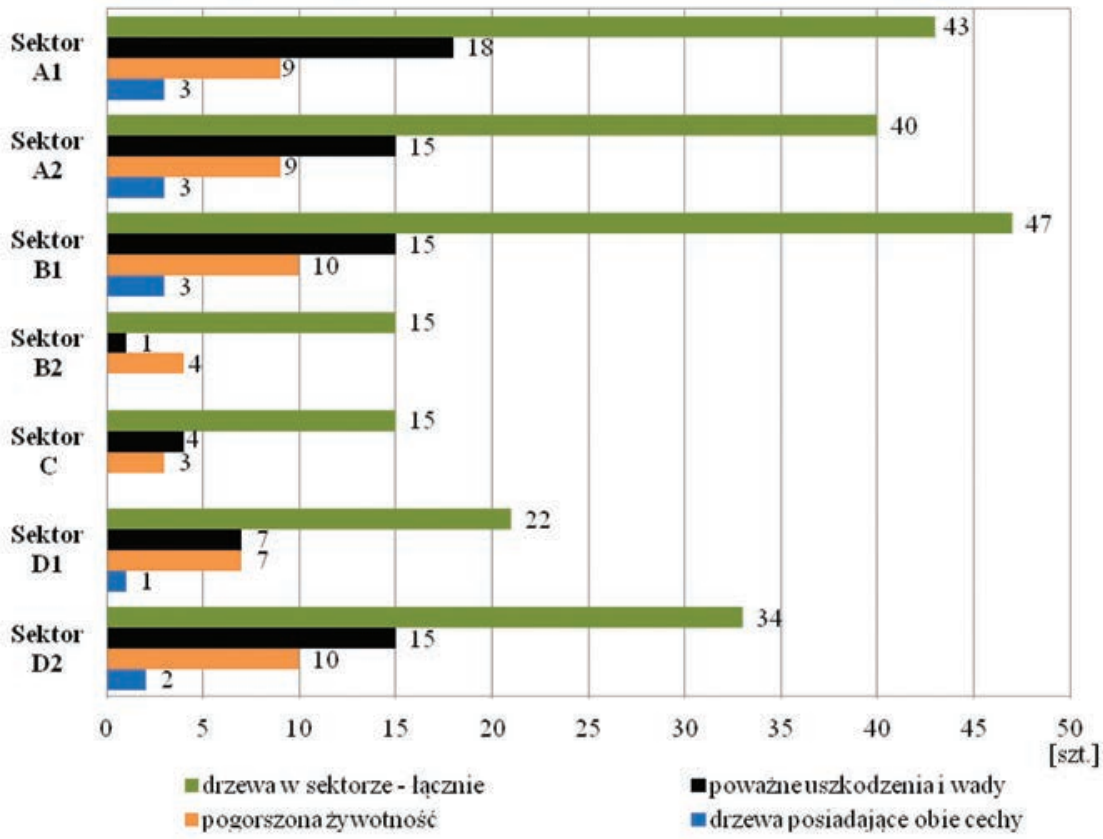

Źródło: B. Fortuna-Antoszkiewicz i in. 2015

Tabela 2. Aleje w Radziejowicach - ocena stanu drzew w podsektorach

\begin{tabular}{|l|l|l|l|l|l|l|l|l|}
\hline \multirow{2}{*}{ Kategoria } & \multicolumn{9}{|c|}{ Sektor } & \multirow{2}{*}{ Aleja } \\
\cline { 2 - 9 } & A1 & A2 & B1 & B2 & C & D1 & D1 & \\
\hline Drzewa w sektorach - łącznie (szt.) & 43 & 40 & 47 & 15 & 15 & 21 & 33 & 213 \\
\hline Silne uszkodzenia i wady (szt.) & 18 & 15 & 15 & 1 & 4 & 7 & 15 & 75 \\
\hline udział procentowy (\%) & 42 & 38 & 32 & 7 & 27 & 33 & 45 & 35 \\
\hline Pogorszona żywotność (szt.) & 9 & 9 & 10 & 4 & 3 & 7 & 10 & 52 \\
\hline udział procentowy (\%) & 21 & 23 & 21 & 27 & 20 & 33 & 30 & 24 \\
\hline Drzewa z obiema cechami (szt.) & 3 & 3 & 3 & - & - & 1 & 2 & 12 \\
\hline udział procentowy (\%) & 7 & 8 & 6 & - & - & 5 & 6 & 6 \\
\hline
\end{tabular}

Źródło: B. Fortuna-Antoszkiewicz i in. 2015 
Część egzemplarzy drzew pozostaje w pogorszonym stanie w związku z ich stadium rozwojowym (drzewa najstarsze - stadium senilne). Jednak część symptomów złego stanu zdrowotnego związana jest w dużym stopniu z prowadzonymi w latach minionych (szczególnie lata 70. i 80. XX wieku) zabiegami z zakresu tzw. „chirurgii drzew” lub „leczenia drzew" (fot. 11, fot. 12).

- 52 drzewa (blisko 1/4 - ok. 24\% wszystkich drzew) wykazuje symptomy pogorszonej żywotności np.: zamieranie koron, pogorszone listnienie, posusz gałęzi, owocniki grzybów pasożytniczych drewna i in.;

- 75 sztuk drzew, czyli 35\% (ponad 1/3) ma różnego rodzaju wyraźne uszkodzenia pni np. odpadanie lub powierzchniowe odarcia kory z martwicą drewna, pękanie pni (wgłębne ubytki zamknięte), a także dziuple (wgłębne ubytki otwarte) z objawami rozkładu drewna (np. różne rodzaje zgnilizny z martwicą i murszem), wywoływanymi m.in. przez patogeny grzybowe i drobnoustroje (fot. 11);

- w całym zespole występuje 6\% drzew mających obie te cechy (tabela 2).

Decydujący wpływ na stan drzew, zwłaszcza pozostających w stadium senilnym, mają współczesne warunki siedliskowe i przestrzenne.

\section{Fot. 11. Al. Lipowa - przykład drzewa z poważnym uszkodzeniem - potężny ubytek wgłębny po wyłamanym przewodniku, dziupla z wewnętrznym rozkładem drewna (nr inw. 20, podsektor A1)}

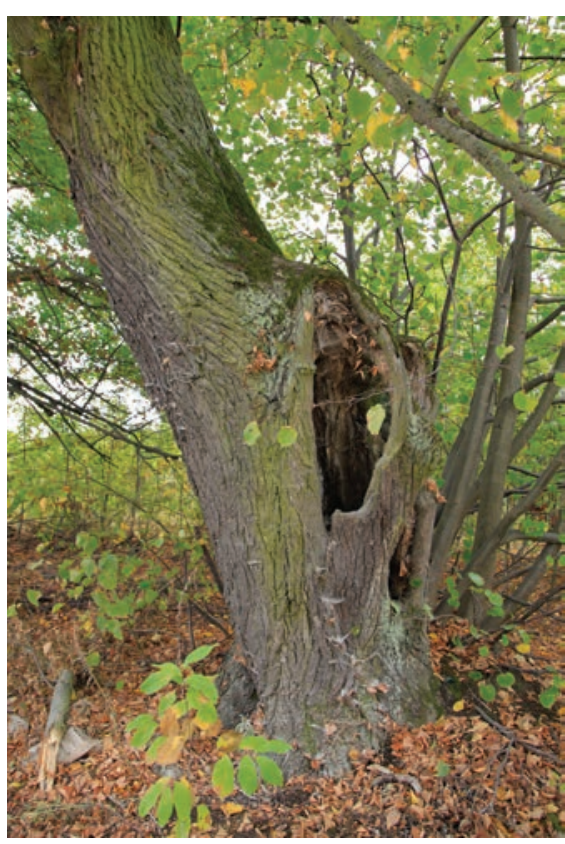

Aleje zakładane jako drogi z przeznaczeniem dla ruchu pieszego lub konnego, o niewielkiej intensywności użytkowania niejednokrotnie, $\mathrm{z}$ biegiem lat, przekształciły się $\mathrm{w}$ ruchliwe trasy komunikacyjne [Majdecki 1993]. Stopniowy wzrost natężenia ruchu kołowego często jest efektem zmian w sposobach zagospodarowania otoczenia (np. intensyfikacja zabudowy, rozwój usług). Związane $\mathrm{z}$ tym modernizacje dróg (przebudowy nawierzchni, zakładanie podziemnej infrastruktury technicznej) prowadzone $\mathrm{w}$ bezpośrednim otoczeniu drzew przydrożnych powodują redukcję i uszkodzenia systemów korzeniowych. Skutkuje to znacznym osłabieniem i nieodwracalną w skutkach degradacją zwłaszcza starych drzew (tzw. ,"spirala śmierci"). Prace budowlane (przemieszczanie się ciężkiego sprzętu, składowanie materiałów budowlanych, zanieczyszczenie gleby itp.) zwykle przebiegają $\mathrm{w}$ pasie znacznie szerszym niż granice drogi. Negatywne skutki budowy są zwykle nieodwracalne [Fortuna-Antoszkiewicz, Łukaszkiewicz 2012b].

Fot. P. Wiśniewski, wrzesień 2015 
Fot. 12. Al. Lipowa - na pierwszym planie sędziwa lipa drobnolistna $z$ drastycznie podkrzesaną koroną (nr inw. 24, podsektor A1)

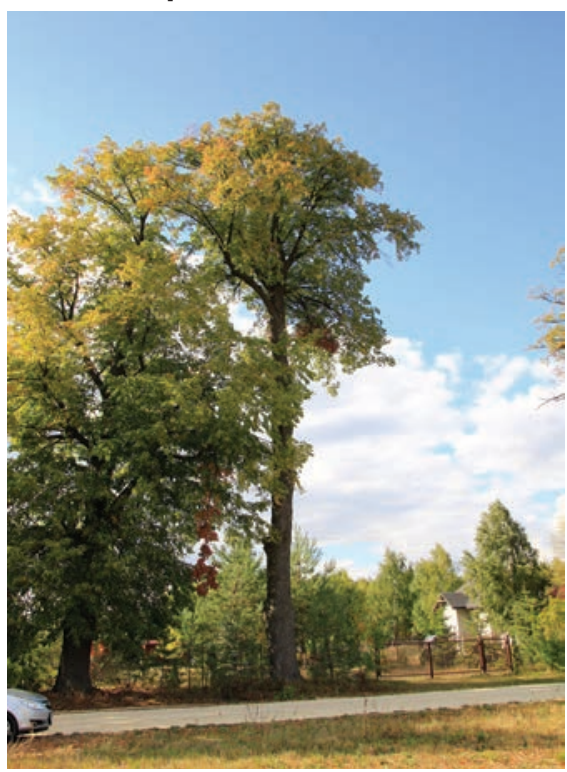

Fot. P. Wiśniewski, wrzesień 2015

niowe drzew. Są to: nadmierne zagęszczenie podłoża, obniżenie wilgotności, zanieczyszczenia chemiczne, zasolenie.

Nadmierne zagęszczenie gleby jest czynnikiem, który jest uznawany za zagrażający $\mathrm{w}$ najwyższym stopniu rozwojowi drzew. Wzrost zagęszczenia podłoża skutkuje zniszczeniem struktury gruzełkowatej, która jest wynikiem naturalnego procesu formowania gleby. Zmniejszeniu ulega przeciętna wielkość porów wypełnionych powietrzem (występujących w glebie przestrzeni niekapilarnych). Wraz ze zmniejszaniem się przestrzeni makroporów zmniejszona zostaje infiltracja wody i wymiana gazowa, spada stężenie tlenu w glebie, a wzrasta stężenie dwutlenku węgla, nawet do ilości toksycznych.
Wzrastające natężenie ruchu kołowego jest także przyczyną licznych uszkodzeń mechanicznych drzew np. w wyniku kolizji drogowych czy przemieszczania się samochodów o gabarytach niemieszczących się w świetle alei. Tego typu zdarzenia często stają się pretekstem do nieuzasadnionego, nadmiernego podkrzesywania koron drzew przydrożnych (fot. 13, fot. 14).

Drzewa rosnące w niesprzyjających warunkach drogowych narażone są na działanie wielu negatywnych czynników, które powodują spadek wydajności procesów fizjologicznych oraz wyraźne skrócenie czasu życia drzew. Stan zdrowotny drzew alejowych uzależniony jest od kilku czynników związanych z warunkami gruntowymi, oddziałującymi na systemy korze-

Fot. 13. Ul. Jakuba Kubickiego (sektor D).

Fragment alei znajdujący się obecnie w strefie zwiększonego ruchu lokalnego. Podkrzesanie koron oraz smukłe sylwetki drzew - rezultat silnego cięcia grubych konarów i gałęzi w skrajni drogi

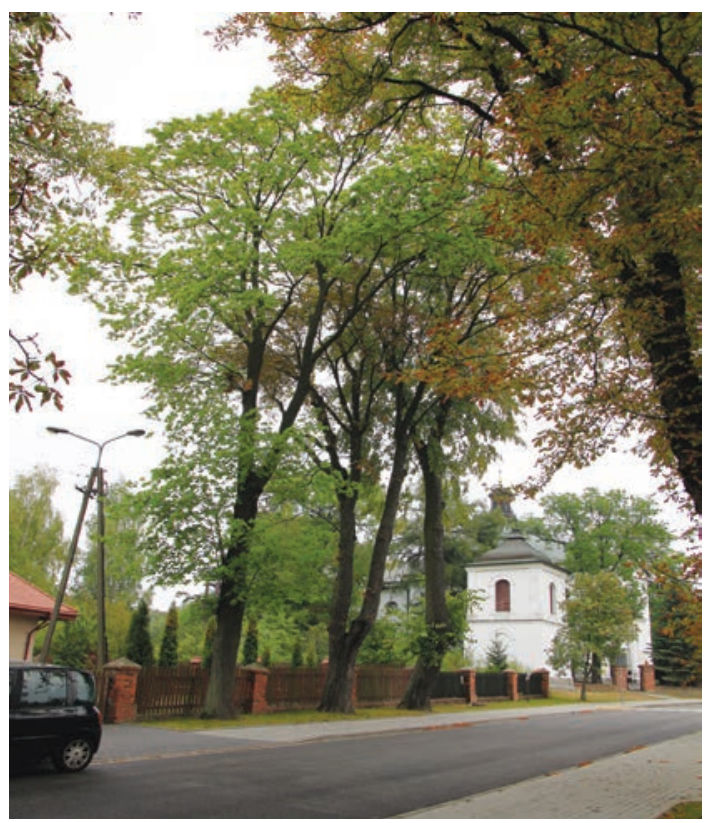

Fot. P. Wiśniewski, wrzesień 2015 
Fot. 14. Ul. Jakuba Kubickiego (sektor D). Ogłowiona sędziwa lipa drobnolistna $z$ wielkim kikutem dł. 4,0 $\mathrm{m}$ nad ulicą i resztką korony ze starym wiązaniem linowym (nr inw. 7, podsektor D1) - efekt lokalizacji drzewa przy współczesnej, ruchliwej ulicy dawnym trakcie

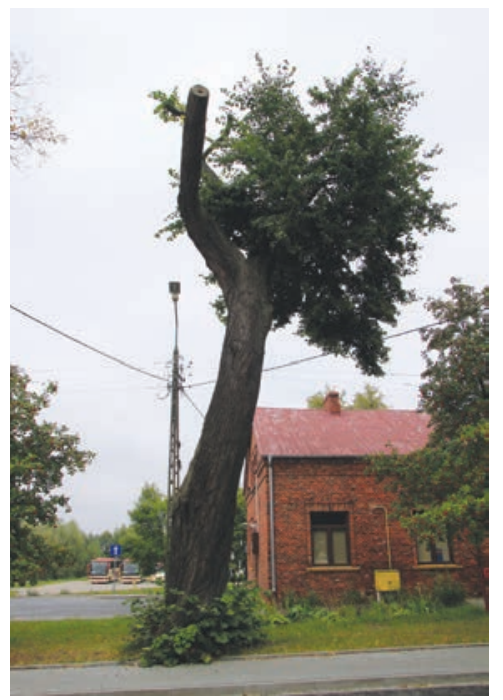

Fot. P. Wiśniewski, wrzesień 2015
Negatywne zmiany stopnia zagęszczenia podłoża drzew przydrożnych zachodzą szczególnie w wierzchniej warstwie gleby o miąższości $0,0-1,0 \mathrm{~m}$ p.p.t. Ma to szczególne znaczenie, jeśli wziąć pod uwagę fakt, że większość gatunków drzew rozwija główną masę korzeni (nawet 70-90\% całego systemu korzeniowego) tuż pod powierzchnią gruntu, w górnej 30-centymetrowej warstwie gleby [Bernatzky 1979; Zimmermann, Brown 1981; Tomanek 1997; Szczepanowska 2001; Fortuna-Antoszkiewicz B., Łukaszkiewicz 2012b].

Właściwości podłoża w strefie korzeniowej drzew uzależnione są w warunkach drogowych od rodzaju pokrycia terenu (np. powierzchnia trawiasta, nawierzchnia gruntowa lub nieprzepuszczalna nawierzchnia utwardzona), a także odległości krawędzi jezdni od pni drzew.

Nadmierne zagęszczanie podłoża oraz redukcje zasięgu korzeni skutkują:

- wyraźnym pogorszeniem się ogólnego stanu zdrowotnego drzew (wydzielanie posuszu, nasilenie aktywności patogenów, wypadanie drzew) (fot. 14);

- zaburzeniem statyki drzew i zdecydowanym wzrostem ryzyka wykrotów [Fortuna-Antoszkiewicz, Łukaszkiewicz 2012b].

Taka sytuacja powoduje, że $\mathrm{w}$ badanym obiekcie obserwuje się stopniowe zanikanie układu alejowego, szczególnie w obrębie centrum miejscowości - na tym obszarze, na odcinku ul. Głównej (sektor C), następuje wyraźne ustępowanie drzew. Drzewa rosną w bardzo nieregularnych odstępach; od strony ogrodzenia parku (strona południowa) - praktycznie drzew brak.

\section{Datowanie układu}

Ocena wieku i czasu powstania układu alejowego w Radziejowicach opierała się na badaniach historycznych (kwerenda materiałów archiwalnych) oraz badaniach bezpośrednich w obiekcie - poprzez ocenę wieku drzew tworzących aleje (na podstawie pomiaru obwodów pni drzew oraz liczby słojów na starych ściętych karpach, fot. 15) [Łukaszkiewicz 2010].
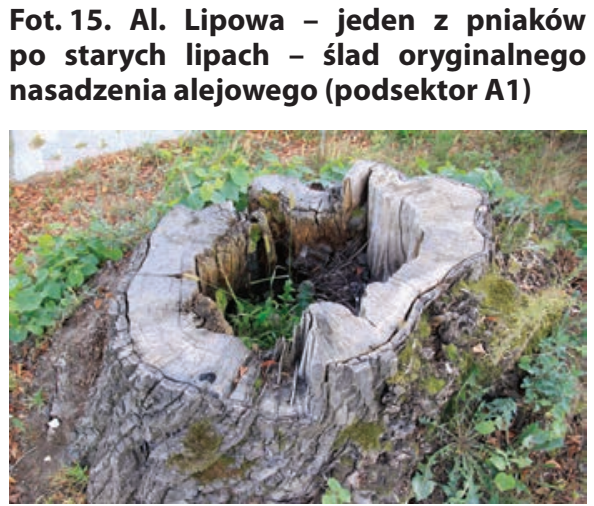

Fot. P. Wiśniewski, wrzesień 2015 
Jak wspomniano już wcześniej, radziejowicki zespół alejowy - w postaci rozbudowanego układu - w głównej mierze powstał ok./po 1820 r. Wyraźnie potwierdzają to badania drzewostanu alejowego, w tym wieku tworzących go drzew - szczególnie grupy najstarszych egzemplarzy lip rosnących w alei Lipowej (sektor A).

Wiek drzew oszacowano zliczając roczne przyrosty drewna na ściętych pniach (stare karpy); w miejscach ubytków wewnętrznych wykonano interpolację; zmierzono obwody pni u podstawy, a następnie daną wartość pomniejszono o ok. 10\%, aby uzyskać prawdopodobne obwody na standardowej wysokości 1,3 m (cm):

- obwód $446 \mathrm{~cm}$ / mierzony na wys. 0,7 m potencjalny obwód na wys. 1,3 m: ok. 400 cm/ liczba słoi: ok. $190=$ ok. 190 lat

- obwód $334 \mathrm{~cm}$ / mierzony na wys. 0,5 m potencjalny obwód na wys. 1,3 m: ok. $300 \mathrm{~cm} /$ liczba słoi: ok. $180=$ ok. 180 lat

Zatem można przyjąć, że lipy o aktualnych obwodach pnia na wys. 1,3 m przekraczających 300 cm mają ok. 180-190 lat (przedział szacunku uwzględnia indywidualne, różne tempo wzrostu poszczególnych egzemplarzy drzew - wynik cech osobniczych).

W zespole alej występuje obecnie 31 sztuk drzew o obwodach pni od $300 \mathrm{~cm}$ wzwyż, czyli w wieku powyżej 180 lat (cenne zasoby materialne).

\section{Stan zachowania całości układu}

Klasyczna aleja - jest to droga piesza lub kołowa rytmicznie obsadzona rzędami drzew. Stanowi jeden z podstawowych składników (element ogrodowy) rozwiniętych kompozy-

\section{Fot. 16. Al. Lipowa - wiatrołom po burzy (VII 2015), sektor A; na takie czynniki narażone są przede wszystkim drzewa o znacznie obniżonej witalności, uszkodzone w poważnym stopniu, o pogorszonej statyce}

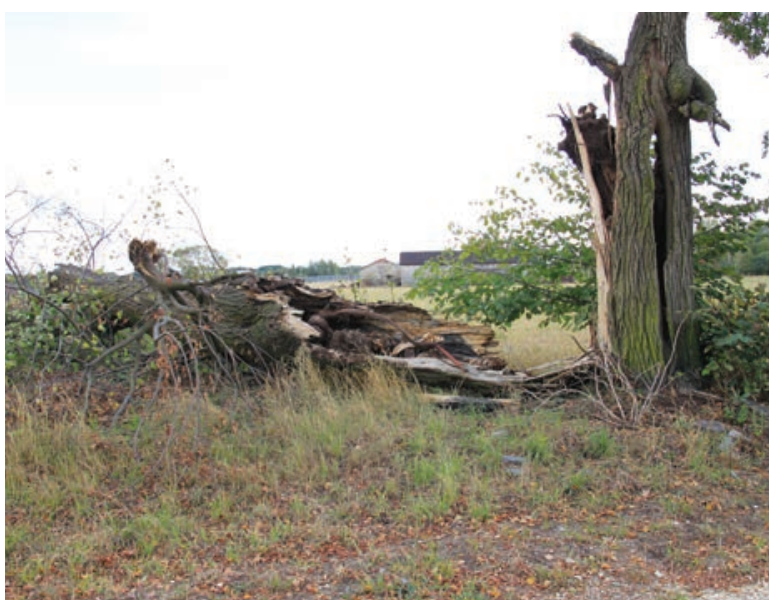
cji ogrodowych, a także założeń urbanistycznych. Może występować samodzielnie, jako forma kształtowania krajobrazu (np. aleja śródpolna) lub wyznaczania przestrzeni reprezentacyjnej (np. aleja miejska). Stanowi wówczas swoisty, niezależny układ ogrodowy o rygorystycznej kompozycji [Fortuna-Antoszkiewicz 2012].

W analizowanym obiekcie obserwuje się nieuchronny proces wypadania starych drzew (fot. 16). W wielu miejscach zanika oryginalny rytm starych nasadzeń, wypadają oryginalne egzemplarze drzew (np. lipy w al. Lipowej) lub nieco późniejsze uzupełnienia. 
Wiele egzemplarzy uznanych za cenne (względy botaniczne, kompozycyjne, krajobrazowe) pozostaje w złym stanie zdrowotnym lub stopniowo zatraca walory dekoracyjne (deformacje pokroju). Obserwuje się zatem przerzedzenie drzewostanu i zatracanie wyraźnej kompozycji układu - rygorystycznej, regularnej formy przestrzennej.

$\mathrm{Z}$ badań terenowych wynika, że oryginalna rozstawa drzew (czyli odległość pomiędzy kolejnymi drzewami) na najlepiej zachowanym odcinku (pod względem występowania oryginalnych ok. 190-letnich lip) czyli w alei Lipowej wynosiła ok. 8,0 m. Wartość minimalna rozstawy na tym odcinku to 7,0 m; wartości pośrednie: 7,5 / 7,7 / 8,0 (występują najczęściej) / 8,5 m; wartość maksymalna to $9,0 \mathrm{~m}$.

Biorąc pod uwagę średnią wartość odległości pomiędzy kolejnym drzewami (ok. 8,0 m) przeliczono liczbę drzew istniejących (bez względu na ich wiek i poprawność gatunkową) oraz ubytków jednostkowych w alei, z uwzględnieniem aktualnych koniecznych luk na wjazdy, skrzyżowania itp. Na tej podstawie określono stopień zachowania układu jako formy przestrzennej, funkcjonującej $\mathrm{w}$ określonych współczesnych warunkach przestrzennych. Stwierdza się, że analizowany układ alejowy (al. Lipowa - ul. H. Sienkiewicza - ul. Główna - ul. J. Kubickiego) obecnie zachowany jest w ok. $36 \%$.
Fot. 17. Ul. Jakuba Kubickiego (sektor D). Widok ogólny alei od kościoła w kierunku południowym; na pierwszym planie największe drzewo w tym sektorze - lipa drobnolistna o obw. $349 \mathrm{~cm}$ (nr inw. 28, podsektor D2)

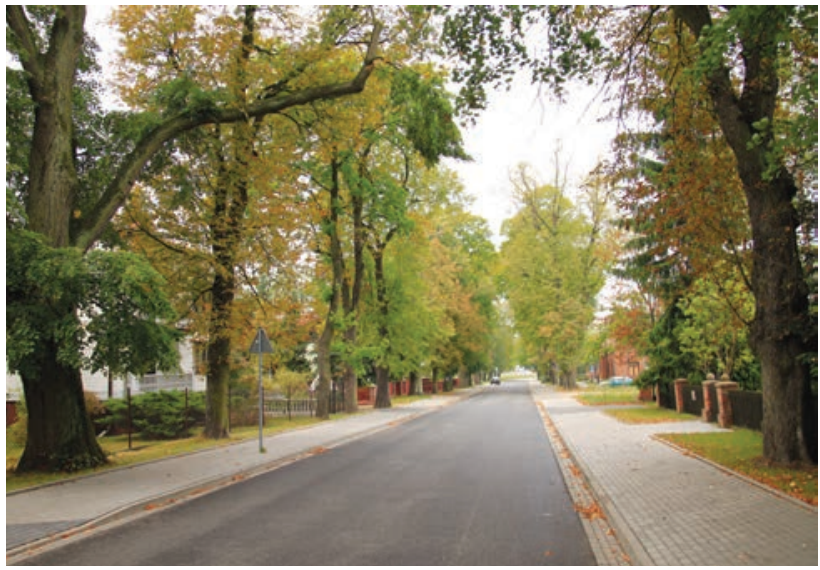

Fot. P. Wiśniewski, wrzesień 2015

Fot. 18. Ul. Jakuba Kubickiego (sektor D). Widok ogólny starodrzewu alei w kierunku północnym. Na zakończeniu osi widokowej - symboliczna dominanta - strzelista topola włoska rosnąca w sąsiedztwie zabytkowego kościoła

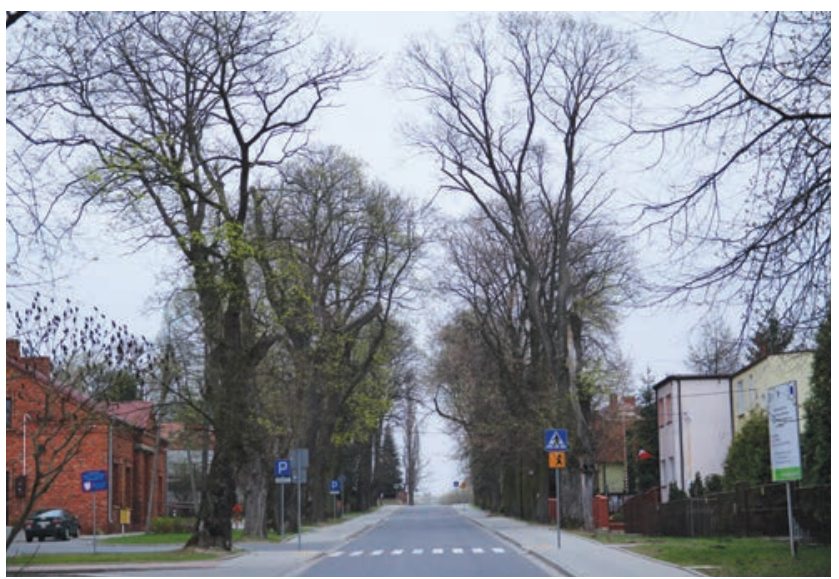

Fot. P. Wiśniewski, kwicień 2016 
Na całej długości układu drzewa rosną nierównomiernie: na fragmentach występują w rozproszeniu, pojedynczo; na fragmentach - układ nasadzeń (forma rzędowa i określony rytm - rozstawa drzew) pozostaje czytelny. Najstarsze drzewa występują głównie w sektorze A (al. Lipowa) - tu układ uległ największemu rozproszeniu i miejscami zanika. W sektorze C (ul. Główna) forma alejowa praktycznie już nie istnieje. W obu sektorach drzewami pierwotnie budującymi aleję były lipy.

W obrębie sektorów B (ul. Sienkiewicza) i D (ul. Kubickiego), gdzie przeważa drzewostan młodszy i przemieszany gatunkowo, w większym stopniu zachowana jest czytelność układu i rytm nasadzeń (rozstawa drzew) (fot.17, fot.18).

\section{Wnioski}

- Generalnie można stwierdzić, że zespół alej w Radziejowicach stanowi niezwykle cenny i unikatowy przykład stosunkowo dobrze zachowanego historycznego układu wielkoprzestrzennego, który nadal krystalizuje strukturę miejscowości -spina dominanty architektoniczno-krajobrazowe (pałac - kościół), wiąże ważne obiekty publiczne (Urząd Gminy, gmachy 2 szkół itp.), wskazuje główne kierunki komunikacyjne.

- Posiada niezbywalne wartości historyczne (nieprzerwane 200 lat istnienia), przyrodnicze (zachowane oryginalne fragmenty nasadzeń - obecność starych, nadal żywotnych egzemplarzy drzew), krajobrazowe (aleje, jako element zachowanej i nadal czytelnej klasycystycznej kompozycji przestrzennej: założenie pałacowo-parkowe - aleje, jako system powiązań - kościół).

- Obiekt, jeszcze zachowany i czytelny, znajduje się w fazie postępującej degradacji całość analizowanego układu alejowego (al. Lipowa - ul. H. Sienkiewicza - ul. Główna - ul. J. Kubickiego) zachowana jest obecnie w ok. $36 \%$.

- Do strat w drzewostanie tworzącym aleje (zamieranie drzew, ubytki w nasadzeniach) przyczyniają się wszystkie zmiany zachodzące w jego otoczeniu, zwłaszcza zmiany funkcji dróg (intensyfikacja ruchu). W związku z tym konieczne są działania zmierzające do poprawienia warunków życiowych drzew [Majdecki 1993]. Ogromne, kluczowe znaczenie ma właściwie prowadzona ich pielęgnacja.

- W ramach ochrony układu wskazane jest m.in. zachowanie najcenniejszych drzewreliktów (egzemplarzy najstarszych - witalnych, cennych pokrojowo), a także wykorzystanie naturalnego materiału roślinnego (oryginalnego materiału genetycznego) - poprzez selekcję i pozostawienie wyrośniętych, korzystnie ukształtowanych odrośli z karp historycznych lip.

Stare aleje w krajobrazie rolniczym Mazowsza i całego kraju są dziś niezwykle cenne z różnych względów - mają niezaprzeczalne walory krajobrazowe, a także niezwykłą wartość historyczną - tworzą żywy pomost między przeszłością a teraźniejszością, stanowią ważny zapis - o czasach, ludziach i zdarzeniach. Należy bezwzględnie dążyć zarówno do zachowania historycznej formy przestrzennej, jak i oryginalnej substancji, jaką są sędziwe drzewa rosnące jeszcze w tych obiektach. 


\section{Literatura}

Barbasiewicz M., 2016, Radziejowickie theatrum. Dzieje rezydencji, wyd. 2. zmienione i uzupełnione, Mazowieckie Centrum Kultury i Sztuki, Radziejowice.

Bernatzky A., 1979, Tree ecology and preservation, Elsevier Scientific Publ. Co., New York.

Fortuna-Antoszkiewicz B., 2002, Kształtowanie roślinności przy drogach - zarys historyczny, Przyroda i miasto, 4, Wydawnictwo SGGW, Warszawa, s. 226-235.

Fortuna-Antoszkiewicz B., 2004, Struktura przestrzenna nasadzeń drzew przy ulicy miejskiej w świetle archizwaliów, Przyroda i miasto, 6, Wydawnictwo SGGW, Warszawa, s. 219-232.

Fortuna-Antoszkiewicz B., 2012, Przemiany formy elementów i układów ogrodowych wzdtuż traktów komunikacyjnych na przykładzie Traktu Królewskiego w Warszawie, Monografie: Sztuka ogrodu, sztuka krajobrazu, 2, Wydawnictwo: Katedra Sztuki Krajobrazu SGGW, Warszawa, s. $1-225$.

Fortuna-Antoszkiewicz B., Łukaszkiewicz J., 2012a, Obsadzanie dróg drzewami owocowymi w Polsce - tradycja i wspótczesność (XIX / XX w.), Czasopismo Techniczne, 9, 111, s. 127-136.

Fortuna-Antoszkiewicz B., Łukaszkiewicz J., 2012b, Wybrane aspekty oddziaływania prac technicznych $i$ zabiegów pielęgnacyjnych na kondycje drzew w parkach zabytkowych, Rocznik Polskiego Towarzystwa Denrologicznego, 60, Wyd. Polskie Towarzystwo Dendrologiczne, Warszawa, s. 77-83.

Fortuna-Antoszkiewicz B., Łukaszkiewicz J., Wiśniewski P., 2015, Inwentaryzacja szczegółowa drzewostanu zespołu alej: al. Lipowa, ul. Henryka Sienkiewicza, ul. Główna, ul. Jakuba Kubickiego, Radziejowice, woj. mazowieckie. Studium obiektu, Maszynopis w zb. Urządu Gminy Radziejowice, 96-325 Radziejowice, ul. Kubickiego 10.

Gradowski L., Budzyński W., 1963, Zadrzewienia w rolnictwie, PWRiL, Warszawa.

Hejmanowski S., Milewski J., Terpiński Z., 1964, Poradnik zadrzewieniowca, PWRiL, Warszawa.

ISA - International Society of Arboriculture. Tree Ordinance Guidelines, http://www.isa-arbor. $\mathrm{com} /$ publications/tree-ord/measuringdbh.aspx.

Łuczyńska-Bruzda M., 1995, Zadrzewienia w krajobrazie otwartym, Krajobrazy, 6, 18, s. 1-48.

Łukaszkiewicz J., 2010, Określanie wieku niektórych gatunków drzew ulicznych na podstawie wybranych parametrów dendrometrycznych, Rocznik Polskiego Towarzystwa Dendrologicznego, 58, Wyd. Polskie Towarzystwo Dendrologiczne, Warszawa, s. 25-38. 
Majdecki L., 1993, Ochrona i konserwacja zabytkowych założeń ogrodowych, Wydawnictwo Naukowe PWN, Warszawa.

Mapa sytuacyjno-wysokościowa w skali 1:500, data wyk. mapy: X 2015 r., obręb: Radziejowice, Radziejowice-Parcel, Kuranów, Wyd. przez Starostwo Powiatowe w Żyrardowie, ul. Limanowskiego 45, 96-300 Żyrardów.

Ortofotomapa $w$ skali 1:5000, Licencja nr GW-4.7522.86.2015.NZ_14_CL1 z dnia 03.09.2015 wydana przez Marszałka Województwa Mazowieckiego, Urząd Marszałkowski Województwa Mazowieckiego w Warszawie, Departament Geodezji i Kartografii, ul. Floriańska 10, 03-707 Warszawa.

Pigott, C. D., 1989, Estimation of the age of lime-trees (Tilia ssp.) in parklands from stem diameter and ring counts, Arboricultural Journal, 13, s. 289-302.

Seneta W., Dolatowski J., 2012, Dendrologia, wyd. 4. zmienione i unowocześnione, Wydawnictwo Naukowe PWN, Warszawa.

Siewniak M., 1990, Gospodarka drzewostanem w założeniach parkowo-ogrodowych, Komunikaty Dendrologiczne, 16, s. 3-48.

Siewniak M., Siewniak Marg., Banzhaf A., 1991, Problemy rekonstrukcji alei w ogrodach zabytkowych na przykładzie centralnej alei w Mosznej, Komunikaty Dendrologiczne, 18, s. 3-33.

Sokołowski J., 1820, Panorama Radziejowic od strony pótnocno-wschodniej, ok. 1820 r., pióro, tusz, akwarela, papier, 13,1x32,8, zb. Muzeum Narodowego w Warszawie, nr inw. Rys. Pol. 161693 MNW.

Studium uwarunkowań i kierunków zagospodarowania przestrzennego gminy Radziejowice, Uchwała nr XLII /213/2006 Rady Gminy w Radziejowicach z dnia 14 września 2006 r. w sprawie uchwalenia studium uwarunkowań i kierunków zagospodarowania przestrzennego Gminy Radziejowice.

Szczepanowska H.B., 2001, Drzewa w mieście, Hortpress, Warszawa.

Szwarc-Bronikowski S., 2000, Świadkowie naszych dziejów, Wydawnictwo Prószyński i S-ka, Warszawa.

Tomanek J., 1997, Botanika leśna, PWRiL, Warszawa.

Zielski A., Krąpiec M., 2004, Dendrochronologia, Wydawnictwo Naukowe PWN, Warszawa.

Zimmermann M.H., Brown C.L., 1981, Drzewa. Struktura i funkcje, PWN, Warszawa. 


\section{Evaluation and preservation of the historical alleys of Radziejowice as the cultural heritage of Mazovia}

\section{ABSTRACT}

The developed study of the historical alley complex in Radziejowice, Mazovia served to determine its exceptional cultural and natural values as a valuable form of roadside plantings which are a remnant of a former, historical system of local highways.

The aim of the study was to inventory the tree resources of selected avenues (in taxonomic, spatial, quantitative and qualitative terms) for the needs of current maintenance and further preservation. The degree of preservation of the original historical stand's resources was also assessed, including an estimation of the age of the original, historical trees. The historical alley complex in Radziejowice was dated according to the results of historical research (archival material query) and field data collection - assessing the age of representative trees forming the alleys. Particularly valuable trees were indicated, including exemplary trees (due to their condition, habit and landscape values), as well as relicts remains of the original nineteenth-century plantings.

The study covered avenues along the streets of Lipowa Av., Henryk Sienkiewicz Str. and Główna Str., which were included in the detailed dendrological inventory. In addition, an assessment of tree health status was carried out (September - October 2015).

The alley complex which is the object of the study was developed in the 1820s and 1830s. The avenues are nowadays characterized by a considerable diversity of the stand and the distinct character of the streets and roads along which they are located. More than half of the trees are small-leaved limes (Tilia cordata Mill.) accompanied by common maples (Acer platanoides L.), horse chestnuts (Aesculus hippocastanum), common hornbeams (Carpinus betulus L.), common ashes (Fraxinus excelsior L.). There are 31 trees with trunk circumference (measured at $1.3 \mathrm{~m} \mathrm{dbh}$ ) of over $300 \mathrm{~cm}$, i.e. over 180 years old (valuable material resources). The degree of preservation of the avenue complex as a spatial form is estimated at about $36 \%$.

Key words: historical alleys, Mazovian landscape, cultural and natural values of avenues, elements of cultural heritage

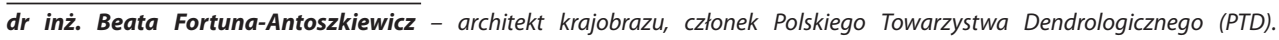
Zainteresowania badawcze: historia, forma i funkcja elementów i układów ogrodowych towarzyszq̨cych ciągom komunikacyjnym; główna domena: przestrzeń publiczna Warszawy; pielęgnowanie, konserwacja i rewaloryzacja parków iogrodów. Kontakt do autora: Katedra Architektury Krajobrazu, SGGW w Warszawie, ul. Nowoursynowska 159, 02-776 Warszawa, www.kak.sggw.pl, e-mail: beata_ fortuna@op.pl

Beata Fortuna-Antoszkiewicz, PhD eng, landscape architect, member of the Polish Dendrology Society (PTD).

Research interests: the history, forms and functions of garden elements arranged along roads and streets; main fields of research: public space of Warsaw; maintenance and a preservation of parks and gardens.

Contact: Department of Landscape Architecture, Warsaw University of Life Sciences - SGGW, 159 Nowoursynowska Str., 02-776 Warsaw, www.kak.sggw.pl, e-mail: beata_fortuna@op.pl

dr inż. Jan Łukaszkiewicz - architekt krajobrazu, członek Polskiego Towarzystwa Dendrologicznego (PTD).

Zainteresowania badawcze: wzrost drzew w obiektach architektury krajobrazu; szacowanie wieku drzew; gospodarka drzewostanem na terenach zurbanizowanych i otwartych z uwzględnieniem kolizji na styku infrastruktury technicznej i szaty roślinnej. Kontakt do autora: Katedra Architektury Krajobrazu, SGGW w Warszawie, ul. Nowoursynowska 159, 02-776 Warszawa, www.kak.sggw.pl, e-mail:

Jan Łukaszkiewicz,PhD eng, Landscape architect, member of the Polish Dendrology Society (PTD).

Research interests: tree stands' management in objects of landscape architecture with regard to the relationship between the trees' condition and technical infrastructure in their surroundings, tree age assessment.

Contact: Department of Landscape Architecture, Warsaw University of Life Sciences - SGGW, 159 Nowoursynowska Str., 02-776

Warsaw,www.kak.sggw.pl, e-mail:jan_lukaszkiewicz@sggw.pl 